\title{
FASILITAS PENANGANAN HEWAN TERLANTAR
}

\author{
Cecilia Evelina ${ }^{1)}$, Nina Carina ${ }^{2)}$ \\ 1)Program Studi S1 Arsitektur, Fakultas Teknik, Universitas Tarumanagara, cecilia.eveli@gmail.com \\ 2) Program Studi S1 Arsitektur, Fakultas Teknik, Universitas Tarumanagara, ninac@ft.untar.ac.id
}

\begin{abstract}
Abstrak
Perkembangan teknologi dan ekonomi masyarakat menjadi salah satu faktor pendorong terjadinya pertumbuhan di suatu lingkungan urban. Perkembangan itu tidak hanya terjadi dalam segi fisik, melainkan juga terdapat pergeseran pada unsur sosial dan budaya dari masyarakat. Sifat masyarakat urban cenderung individualistis, kapitalis, lebih mementingkan kecepatan atau sesuatu yang dianggap instan, serta tidak lagi akrab dengan alam, tumbuhan dan hewan. Hal yang dianggap tidak menguntungkan cenderung disingkirkan. Manusia, hewan dan tumbuhan seharusnya hidup berdampingan meskipun suatu wilayah telah berubah menjadi sebuah kota besar. Keberadaan hewan terlantar merupakan komponen yang tidak dapat terpisahkan di dalam kehidupan di perkotaan. Populasi dari hewan seperti anjing dan kucing jalanan yang terus melonjak tentu akan mempengaruhi ekosistem di dalam perkotaan. Pada akhirnya terganggunya ekosistem itu juga akan turut mempengaruhi kehidupan manusia, seperti meningkatnya penyebaran penyakit dari hewan ke manusia hingga peningkatan kecelakaan di jalanan. Untuk itu diperlukan upaya manusia untuk menangani permasalahan dari hewan jalanan yang sebenarnya juga merupakan bagian yang tidak terpisahkan dari kota, juga upaya mendekatkan kembali interaksi antara manusia kota dengan hewan. Rengkuh Asuh pun hadir menjadi sebuah proyek yang berupaya menjadi wadah penanganan hewan terlantar di jalanan Kota BSD.
\end{abstract}

Kata kunci: Ekologi; Hewan Peliharaan; Hewan Terlantar; Perkotaan; Rengkuh Asuh

\begin{abstract}
The development of technology and society's economy is one of the driving factors for growth in an urban environment. This development does not only occur in physical terms, but there is also a shift in the social and cultural elements of society. The nature of urban society tends to be individualistic, capitalist, more concerned with speed or something that is considered instant and is no longer familiar with nature, plants, and animals. Things that are considered unprofitable tend to be removed. Humans, animals and plants should coexist even if an area has turned into a big city. The existence of abandoned animals is an inseparable component of life in urban areas. The population of animals such as stray dogs and stray cats that continue to soar will certainly affect the ecosystem in urban areas. In the end, the disruption of the ecosystem will also affect human life, such as increasing the spread of diseases from animals to humans to increasing road accidents. For this reason, human efforts are needed to deal with the problems of street animals which are actually an inseparable part of the city, as well as efforts to bring the interaction between city humans and animals closer. Rengkuh is also present as a project that seeks to become a container for handling abandoned animals on the streets of BSD City.
\end{abstract}

Keywords: Ecology; Pet; Stray Animal; Urban; Rengkuh Asuh 


\section{PENDAHULUAN}

\section{Latar Belakang}

Manusia, hewan, dan tumbuhan dalam ekologi adalah makhluk yang setara. Semua unsur dalam ekosistem memiliki perannya masing-masing yang menggerakkan alam semesta. Namun manusia yang dianugerahi akal budi memiliki kemampuan lebih untuk mengatur alam di sekelilingnya untuk mendukung kemudahan kehidupannya. Kemampuan lebih itu menjadikan manusia mampu mengembangkan peradabannya. Perkembangan teknologi dan ekonomi masyarakat menjadi salah satu faktor pendorong terjadinya perkembangan di suatu daerah. Kawasan pedesaan perlahan-lahan berkembang dan bertransformasi menjadi area perkotaan.

Perkembangan itu tidak hanya terjadi dalam segi fisik suatu tempat, melainkan juga terdapat pergeseran pada unsur sosial dan budaya dari masyarakat. Sifat masyarakat urban yang cenderung individualistis, kapitalis, lebih mementingkan kecepatan atau sesuatu yang dianggap instan, serta tidak lagi akrab dengan alam, tumbuhan, dan hewan. Hal yang dianggap tidak menguntungkan cenderung disingkirkan. Manusia, hewan dan tumbuhan seharusnya hidup berdampingan meskipun suatu wilayah telah berubah menjadi sebuah kota besar.

Berbagai penelitian telah membuktikan adanya berbagai manfaat dari berinteraksi dengan hewan terutama hewan peliharaan, dalam menjaga kesehatan mental dan tubuh manusia. Bermain dengan hewan dapat menurunkan stress, mengurangi potensi penyakit jantung, dan menurunkan tekanan darah. Manfaat itu akan juga membantu peningkatan kualitas hidup dari manusia urban. Namun, fenomena bermukim di perkotaan cenderung berkembang ke arah vertikal, di mana biasanya hunian vertikal tidak memperbolehkan penghuninya mempunyai hewan peliharaan menyebabkan masyarakat kota tidak lagi dapat dengan bebas memelihara hewan.

Ledakan populasi hewan jalanan telah menjadi sebuah isu di perkotaan. Kurangnya kepedulian serta penanganan terhadap hewan jalanan menyebabkan terjadinya ledakan populasi hewan jalanan seperti kucing dan anjing liar. Ledakan populasi tersebut pun menimbulkan berbagai masalah seperti semakin maraknya kasus kekerasan pada hewan, penangkapan hewan jalanan secara ilegal untuk dijual dagingnya, juga penyebaran penyakit oleh hewan jalanan yang pada akhirnya juga akan mempengaruhi kehidupan manusia. Untuk itu diperlukan upaya manusia untuk menangani permasalahan dari hewan jalanan yang sebenarnya juga merupakan bagian yang tidak terpisahkan dari kota, juga upaya mendekatkan kembali interaksi antara manusia kota dengan hewan.

\section{Rumusan Permasalahan}

Berdasarkan latar belakang di atas, maka rumusan permasalahan yang muncul adalah, bagaimana perancangan di dalam arsitektur dapat mengembalikan keeratan hubungan antara manusia kota dengan hewan serta bagaimana perancangan di dalam arsitektur dapat menyelesaikan permasalahan ledakan populasi yang terjadi pada hewan terlantar di perkotaan, terutama kucing.

\section{Tujuan}

Berdasarkan identifikasi masalah di atas, maka tujuan dari proyek ini adalah mengetahui cara untuk merancang ruang yang dapat mengembalikan keeratan hubungan antara hewan dan manusia, mengetahui cara untuk merancang suatu program yang berguna untuk meningkatkan kualitas hidup dari kucing dan anjing terlantar di perkotaan, serta mengetahui cara untuk menciptakan wadah dan aktivitas yang dapat menunjang upaya penyelesaian permasalahan ledakan populasi hewan terlantar terutama kucing yang terjadi pada hewan terlantar di perkotaan. 


\section{KAJIAN LITERATUR}

\section{Hewan Peliharaan}

Menurut Undang-Undang Republik Indonesia Nomor 41 tahun 2014 tentang peternakan dan kesehatan hewan pasal 1 ayat 2 dan 3, menyatakan bahwa hewan peliharaan adalah hewan yang kehidupannya untuk sebagian atau seluruhnya bergantung pada manusia untuk maksud dan tujuan tertentu. Sementara berdasarkan Undang-Undang Republik Indonesia Nomor 41 tahun 2014 tentang peternakan dan kesehatan hewan pasal 1 ayat 5 , hewan ternak merupakan adalah hewan peliharaan yang produknya diperuntukkan sebagai penghasil pangan, bahan baku industri, jasa, dan atau hasil ikutannya terkait dengan pertanian. Hewan Peliharaan adalah hewan yang dipelihara sebagai teman sehari-hari dari manusia, tidak seperti hewan ternak, hewan pekerja, ataupun hewan tunggangan, hewan peliharaan dirawat bukan untuk melakukan tugas tertentu untuk kepentingan ekonomi. Hewan peliharaan merupakan binatang yang dijinakkan dan diurus oleh pemiliknya, serta memiliki ikatan emosional di antara keduanya. Ikatan emosional akan membentuk sebuah hubungan antara manusia dengan hewan.

Meskipun secara teori manusia dapat memelihara hewan apapun sesuai dengan kemampuan manusia dalam melakukan domestikasi, namun terdapat beberapa hewan yang telah dikenal secara luas dan sangat populer dari masa ke masa menjadi teman hidup dari manusia. Anjing dan Kucing telah dikenal secara luas sebagai dua binatang peliharaan yang banyak dipelihara dan berkeliaran bebas di sekitar kehidupan manusia. Di banyak negara berkembang, anjing dan kucing desa maupun anjing dan kucing kota dapat dengan mudah dijumpai hidup berdampingan dengan manusia (Coppinger, 2001). Sebagai bagian dari mamalia, anjing dan kucing juga memiliki ukuran yang cenderung cukup besar dengan populasi yang lebih banyak yang membuat keberadaannya terasa lebih signifikan sebagai bagian dari kota.

\section{Manfaat dari relasi manusia dengan hewan peliharaan}

Pet attachment atau kelekatan pada hewan peliharaan memberikan banyak manfaat dalam berbagai aspek kehidupan manusia. Salah satu manfaatnya adalah untuk kesehatan, seperti cenderung menurunkan tekanan darah, menurunkan potensi serangan jantung, dan turut memfasilitasi kontak sosial. Tidak hanya bermanfaat untuk kesehatan tubuh, memelihara hewan juga memiliki manfaat positif untuk kesehatan mental. Orang yang memelihara hewan terbukti cenderung memiliki psychological distress dan intensitas mengunjungi dokter yang lebih sedikit dibanding dengan yang tidak memiliki hewan peliharaan, hal itu dibuktikan pada sebuah penelitian oleh Sable (2012). Hal ini juga diperkuat oleh penelitian dari Garrity et al (1988), yang mengatakan bahwa depresi pada lansia secara signifikan dapat berkurang dengan kepemilikan hewan peliharaan.

Persahabatan diyakini merupakan salah satu alasan yang mendasari seseorang untuk memiliki hewan peliharaan. Berbeda dibanding dukungan sosial dari manusia, hewan peliharaan memberikan reward secara intrinsik, seperti perasaan relaksasi dan berbagi kesenangan dan rekreasi Ketika berinteraksi dengan hewan peliharaan (McNicholas, 2000).

\section{Keadaan hewan peliharaan terlantar di Kota saat ini}

Hewan-hewan yang berada di wilayah perkotaan dapat menimbulkan beberapa dampak terhadap populasi manusia jika tidak dikendalikan. Penelitian terdahulu di kota Sao Paulo, Brazil menunjukkan risiko kesehatan seperti penyebaran rabies dan polusi lingkungan dapat ditimbulkan oleh populasi anjing liar yang tidak terkontrol (Guilloux et al., 2018). Perilaku anjing di wilayah perkotaan dipengaruhi oleh aktivitas dan praktik budaya manusia. Relasi yang dibentuk oleh anjing dan manusia dapat berubah tergantung kepada pemanfaatan dari anjing tersebut, seperti untuk berburu atau penjaga. Hal ini berimbas lebih lanjut kepada bagaimana manusia membagi tempat tinggal dengan anjing (Miternique \& Gaunet, 2020). 
Populasi kucing yang tidak terkontrol turut menimbulkan risiko kesehatan bagi manusia. Kucing liar dinilai memiliki efek negatif terhadap keanekaragaman biotik (Kennedy et al., 2020). Pengendalian populasi kucing menjadi tantangan dunia karena risiko yang dapat ditimbulkan dari risiko populasi berlebihan tersebut. Upaya di belahan dunia lain yang diterapkan adalah seperti 2-3 juta kucing ditangkap dan dimasukkan penangkaran setiap tahunnya di Amerika Serikat dan setengah dari jumlah kucing tersebut disuntik mati (euthanasia). Jepang turut menerapkan program kucing komunitas dimana populasi kucing dikontrol dan dirawat oleh residen dari komunitas tersebut (Mitsui et al., 2020). Di Indonesia sendiri, terjadi beberapa kasus viral seperti terkuaknya pejagalan daging kucing untuk dikonsumsi, yang dilaporkan oleh Riska Fitria pada Februari 2021. Juga kasus penganiayaan pada kucing pada Februari ini yang dilaporkan oleh Yogi Ernes. Terdapat juga dapat perkiraan ledakan populasi kucing yang semakin meningkat tajam di tahun 2021 seperti yang ditunjukkan oleh grafik berikut.

\section{Grafik 1. Perkiraan Jumlah Populasi Kucing di Jakarta}

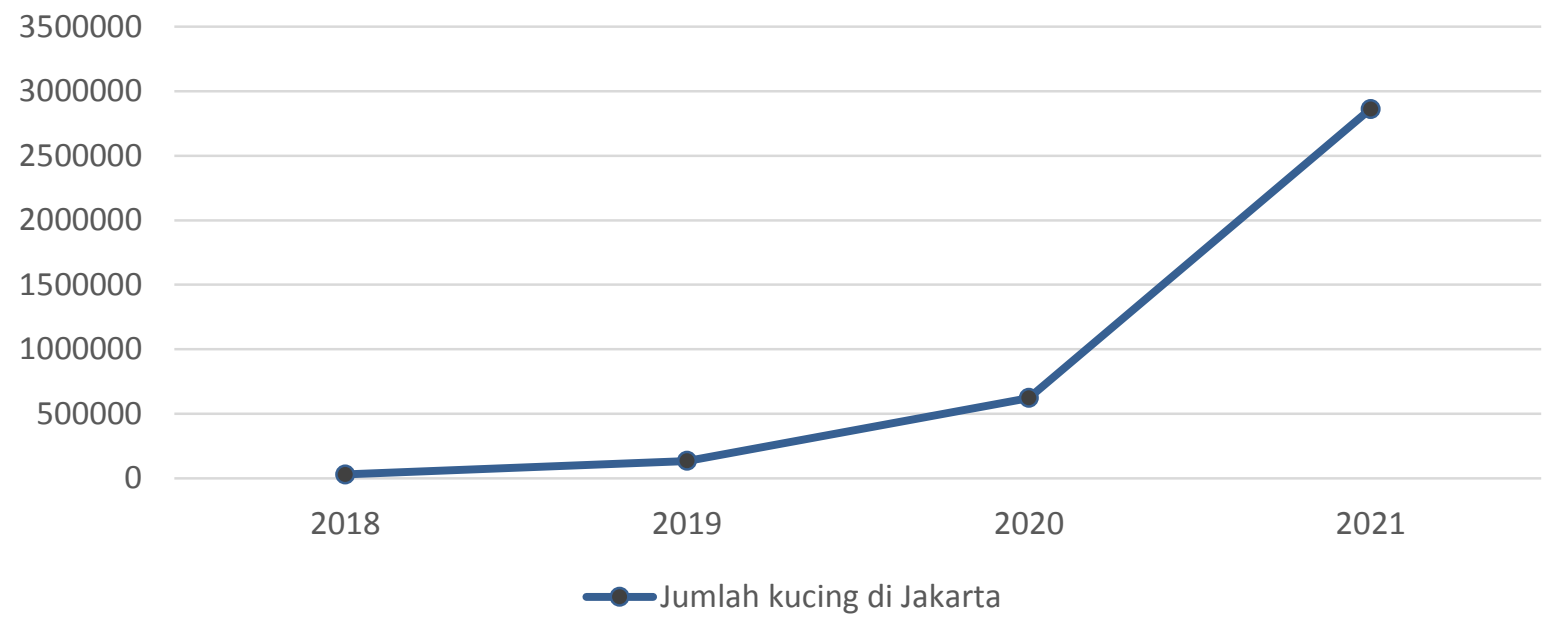

Sumber: Riset Kumparan (2020)

Sebagaimana disebutkan dalam paragraf sebelumnya, populasi anjing yang tidak terkontrol dapat menyebabkan risiko kesehatan seperti penyebaran penyakit rabies. Penyakit rabies dinilai sebagai risiko yang mengkhawatirkan untuk kesehatan publik di negara berkembang. Penelitian dari organisasi internasional mengestimasi jumlah kematian akibat terinfeksi rabies adalah sebanyak 55.000 jiwa tahun (Burgos-Cáceres, 2011). Kasus infeksi rabies dapat dicegah dengan proses vaksinasi pada hewan penular rabies (HPR). Dari tahun 2016-2017, kasus kematian yang terdata dari 25 provinsi di Indonesia mencapai 207 jiwa dari 120.084 kasus infeksi rabies tercatat. Provinsi Bali menjadi provinsi dengan kasus terbanyak dengan 62.504 kasus infeksi rabies (Setiawaty et al., 2019). Kementerian Kesehatan Indonesia telah menggalakkan program untuk menanggulangi dampak dari penyebaran infeksi rabies dengan peluncuran Masterplan Nasional Pemberantasan Rabies di Indonesia (Azhar et al., 2019). Pada Juni 2020 silam terdapat pula sebuah kasus memprihatinkan di Bali di mana seekor anjing dipukul hingga mati (Riza, 2020). Ledakan populasi dan penyebaran penyakit dapat diatasi dengan sterilisasi dan vaksinasi.

\section{METODE}

Jenis Penelitian yang dilakukan adalah jenis deskriptif-kualitatif, yakni adalah sebuah teknik yang menggambarkan dan menginterpretasikan arti data-data yang terkumpul untuk memperoleh gambaran secara umum dan menyeluruh tentang keadaan sebenarnya.

\section{Metode Pengumpulan Data}


Pengumpulan data dilakukan dengan mengumpulkan data sekunder melalui berbagai sumber, antara lain melalui studi literatur berupa buku, jurnal, laporan penelitian dan artikel menjadi sumber informasi dan data utama untuk melakukan penelusuran isu dan rancangan.

\section{Metode Kompilasi}

Setelah melakukan pengumpulan data, data-data tersebut kemudian dikumpulkan dan dikompilasi untuk dianalisis yang kemudian menghasilkan suatu strategi dan poin-poin penting di dalam perancangan.

\section{Metode Perancangan}

Perancangan proyek mengambil metode pendekatan berdasarkan tingkah laku hewan yakni kucing, yang diimplementasikan ke dalam desain berupa banyaknya sirkulasi vertikal yang menggunakan ramp. Selain itu digunakan metode metafora yakni mengambil bentuk dari kiasan atau perumpamaan dari suatu objek yang diimplementasikan ke dalam bentuk bangunan.

\section{DISKUSI DAN HASIL}

\section{Lokasi}

Kawasan BSD Tangerang Selatan dipilih menjadi lokasi program karena BSD merupakan salah satu kawasan di Jabodetabek yang belum memiliki sentra penanganan hewan terlantarnya sendiri. Hal itu dapat diamati dari ilustrasi pemetaan tempat penampungan hewan pada gambar 1.

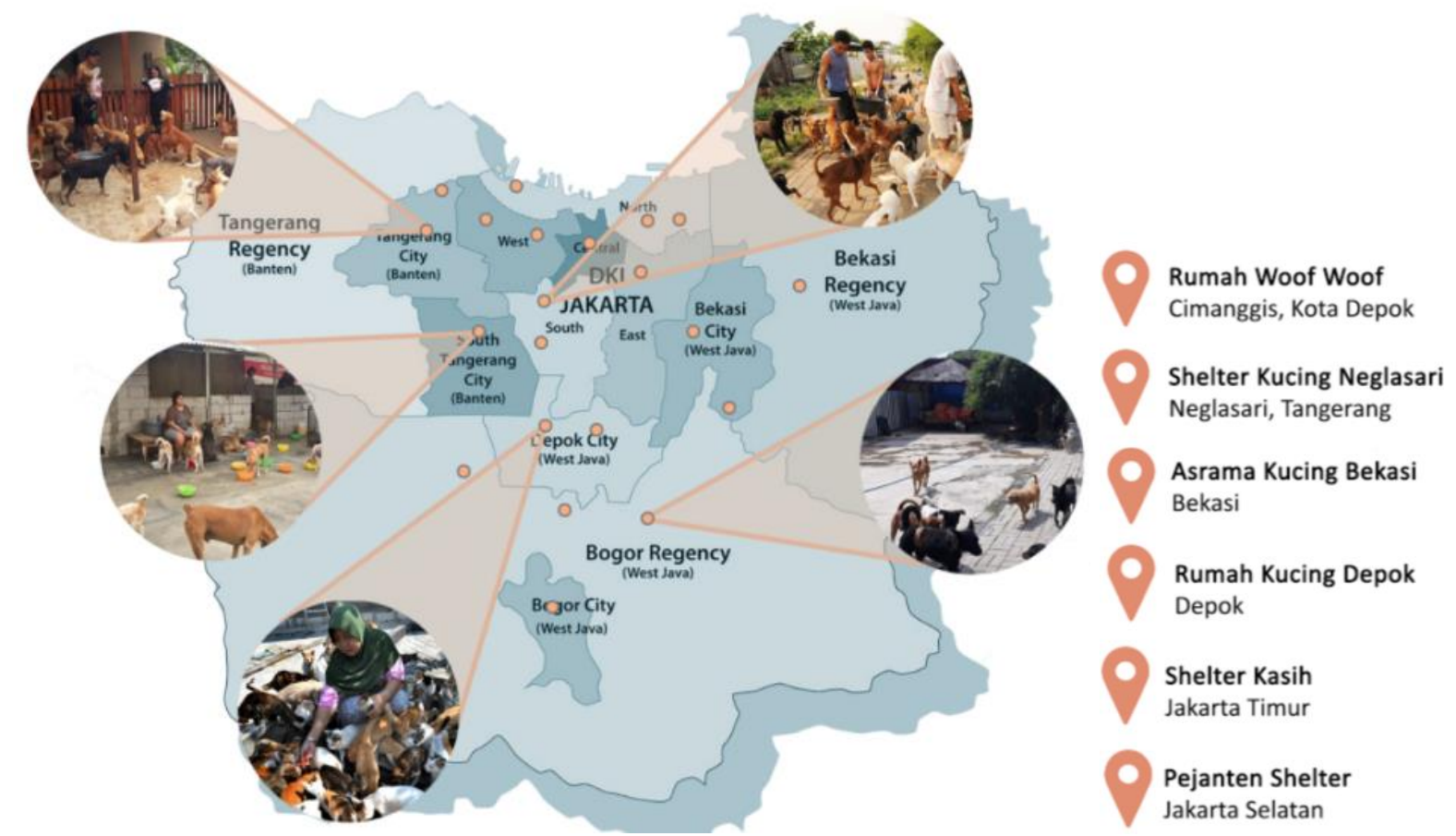

Gambar 1. Pemetaan Tempat Penampungan Hewan Terlantar di Jabodetabek Sumber: Penulis ,2021

Selain itu Kawasan BSD juga memenuhi kriteria pencarian lokasi yaitu merupakan daerah perkotaan, berada dekat dengan area pemukiman penduduk, mudah diakses oleh masyarakat dan dapat diakses oleh sarana prasarana umum.

\section{Data Tapak}

Lokasi: JL. Boulevard BSD Timur, No. 31, Serpong, Tangerang Selatan, Banten

Luas Tapak: $5.600 \mathrm{~m} 2$ 


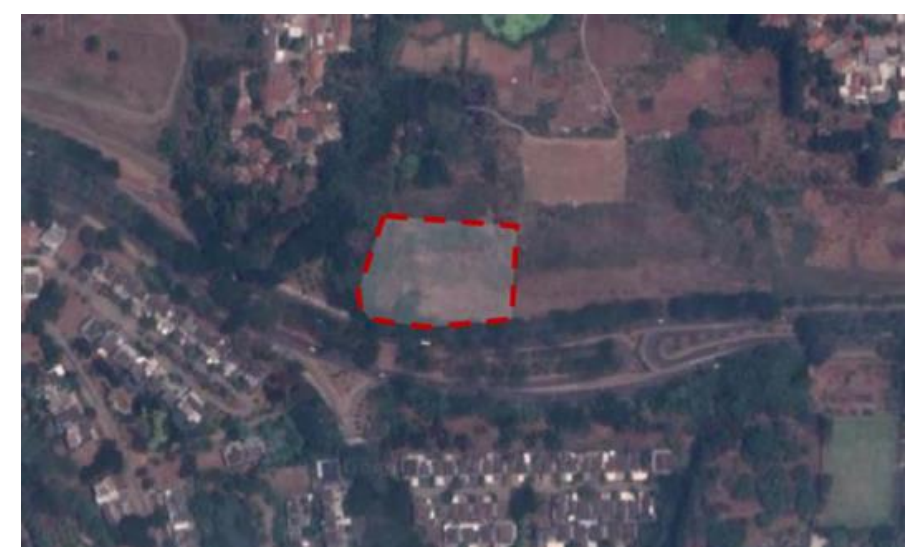

Gambar 2. Tapak Terpilih

Sumber: Penulis ,2021

\section{Analisis Penggunaan Lahan Sekitar}

Sekitar tapak merupakan permukiman dan bangunan komersil KDB rendah, seperti yang digambarkan di gambar 3.

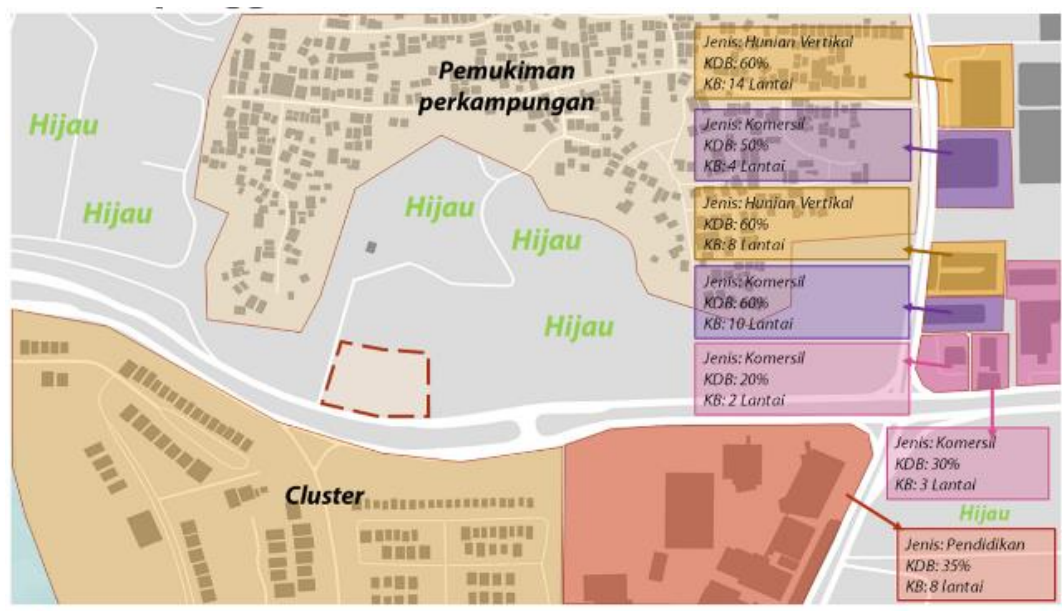

Gambar 3. Pemetaan Penggunaan Lahan Sekitar Tapak

Sumber: Penulis ,2021

Berdasarkan analisis penggunaan lahan sekitar, tapak diasumsikan menjadi lahan tipe K3 yaitu komersil KDB rendah.

KDB: $40 \%$

KLB: 2

$\mathrm{KDH}: 30 \%$

\section{Program}

1. Penampungan hewan terlantar

Merupakan sebuah tempat untuk menampung anjing dan kucing terlantar yang perlu ditampung. Menjadi sebuah wadah kampanye untuk tidak lagi membeli hewan peliharaan, melainkan melakukan adopsi pada hewan-hewan yang membutuhkan pemilik. Hewan-hewan seperti anjing dan kucing direscue atau diselamatkan dari jalanan ataupun tempat jagal hewan. Masyarakat dapat dengan aktif melaporkan hewan-hewan yang perlu diselamatkan untuk dijemput oleh petugas. Pendanaan dari program ini juga dapat berasal dari donasi, biaya pengadopsian, dan keuntungan dari pet hotel dan pet café.

\section{Pet hotel}

Mengakomodir para pecinta hewan yang memiliki keinginan untuk memiliki hewan, tapi terkendala karena huniannya (apartemen / kontrakan / kosan) yang tidak mengijinkan untuk memelihara hewan. 
Masyarakat dapat menitipkan hewan kesayangannya di tempat ini.

3. Pet café

Tempat di mana manusia dapat menikmati waktunya dengan berinteraksi dengan hewan secara dekat. Pengunjung dapat menikmati makanan dan minuman yang tersedia sembari mengelus dan bermain dengan hewan yang ada di sana. Hewan-hewan yang disediakan untuk menemani pengunjung adalah anjing dan kucing.

\section{Pet Shop}

Mengakomodir kebutuhan para pecinta hewan untuk membeli perlengkapan ataupun peralatan untuk merawat hewan peliharaan.

5. Ruang terbuka ramah hewan

Masyarakat bisa menghabiskan waktu untuk bersosialisasi dengan manusia dan hewan secara bebas dan nyaman.

\section{Alur Kegiatan}

1. Shelter Hewan Terlantar

Alur rescue di shelter hewan terlantar dibedakan berdasarkan klasifikasi hewan rescue berikut ini.

Tabel 1. Klasifikasi Penggolongan Hewan Rescue

\begin{tabular}{|c|c|c|}
\hline No & Kondisi & Penanganan \\
\hline \multicolumn{3}{|c|}{ Berdasarkan kondisi kesehatan } \\
\hline 1 & Sehat & Kandang bersama \\
\hline 2 & Cidera sementara & Kandang rehabilitasi \\
\hline 3 & Cacat permanen & Area rehabilitasi \\
\hline 4 & Sakit menular & R. Isolasi \\
\hline 5 & Sakit tidak menular & Kandang rehabilitasi \\
\hline 6 & Malnutrition & Area rehabilitasi \\
\hline \multicolumn{3}{|c|}{ Berdasarkan kondisi psikologis } \\
\hline 1 & Normal / friendly & Kandang bersama \\
\hline 2 & Stress & Area rehabilitasi \\
\hline 3 & Trauma & Area rehabilitasi \\
\hline 4 & Temprament & Kandang rehabilitasi \\
\hline
\end{tabular}

Sumber: Penulis ,2021

Pembedaan kondisi dari hewan rescue menjadikan terdapat pembedaan tempat penampungan sesuai dengan kondisi hewan yang direscue seperti ilustrasi pada gambar 4. 


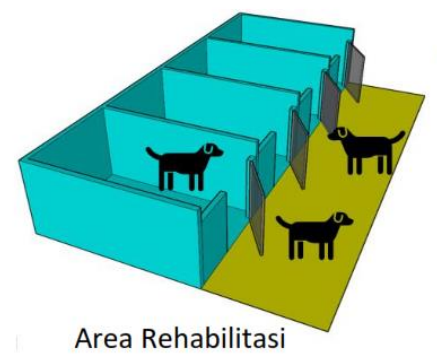

Area Rehabilitasi

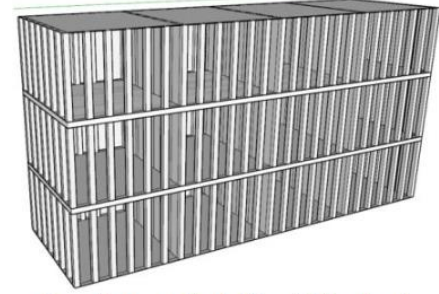

Kandang Rehabilitasi / Isolasi

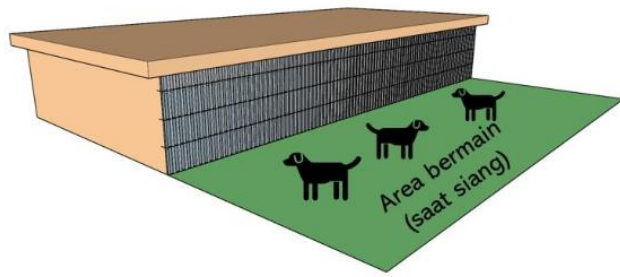

Kandang Bersama (anjing)

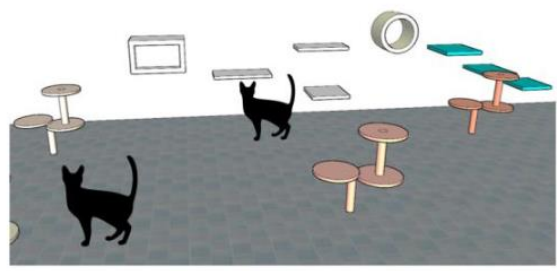

Kandang Bersama (kucing)

Gambar 4. Ilustrasi Tempat Penampungan Hewan Sumber: Penulis , 2021

\section{Alur Rescue}

Alur rescue dimulai dari pertama kali hewan direscue atau dibawa masuk ke dalam shelter, hingga ke kandang bersama di mana hewan akan hidup selanjutnya.

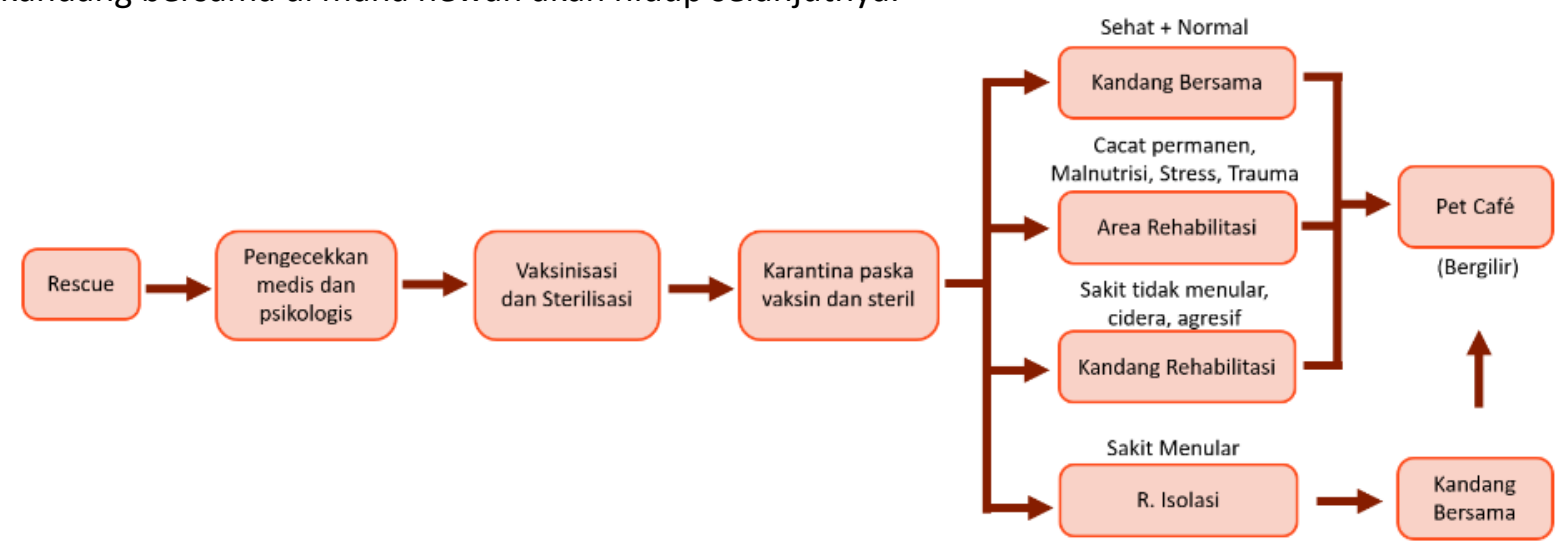

Gambar 5. Diagram Alur Kegiatan Shelter Sumber: Penulis, 2021

\section{Alur Penitipan Hewan di Pet Hotel}

Alur penitipan hewan dimuali dari registrasi, lalu dilanjutkan dengan pengecekan kutu. Lalu hewan peliharaan akan mendapatkan kamar masing-masing untuk menginap.

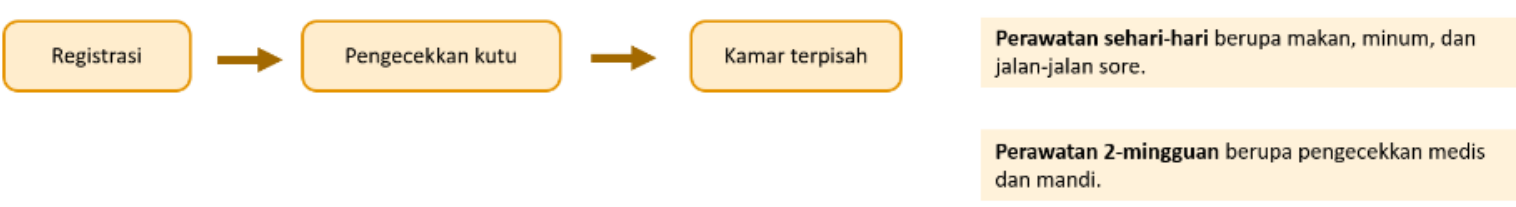

Gambar 6. Diagram Alur Kegiatan Pet Hotel

Sumber: Penulis , 2021

\section{Hubungan Antar Program}

Diantara fungsi-fungsi yang telah ditentukan, ditetapkan pula keeratan hubungan antar program yang akan menentukan desain peletakan tiap program seperti yang digambarkan pada diagram berikut ini. 


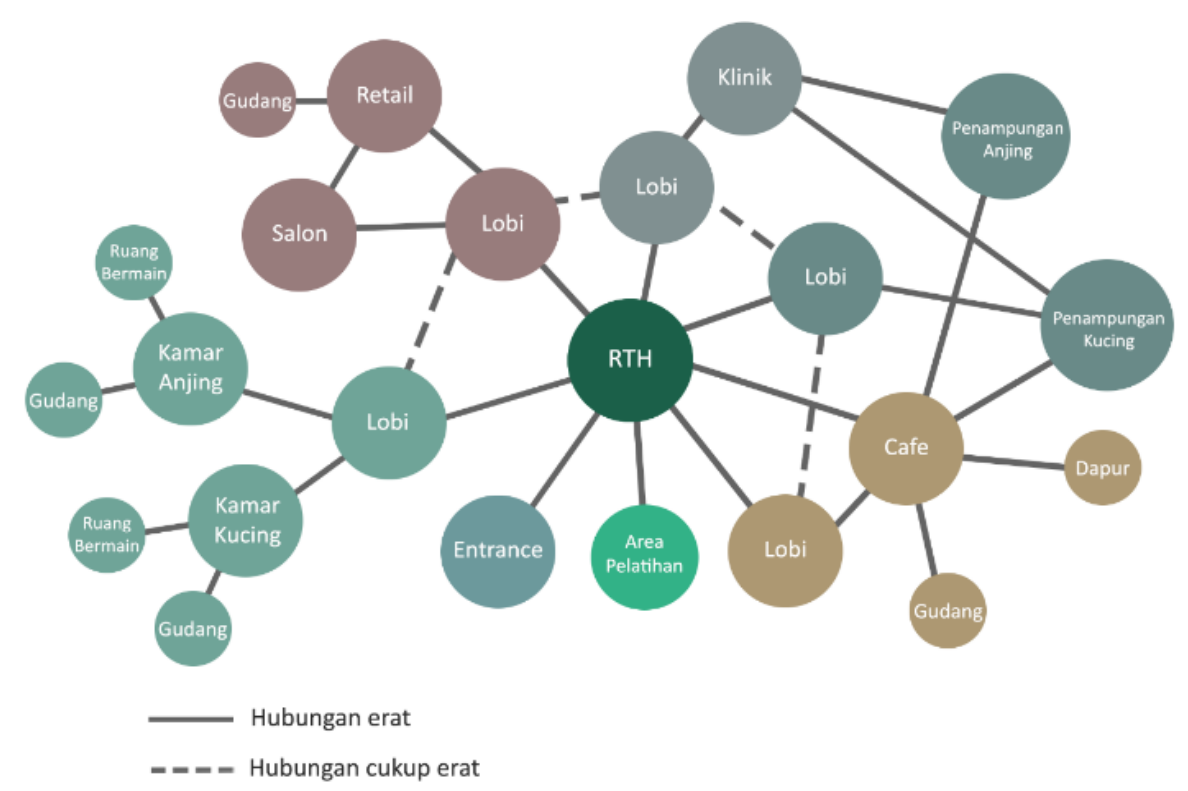

Gambar 7. Diagram Hubungan Antar Program Sumber: Penulis, 2021

\section{Perhitungan Program}

Berikut ini merupakan hasil perhitungan program yang telah diterapkan ke dalam gubahan massa.

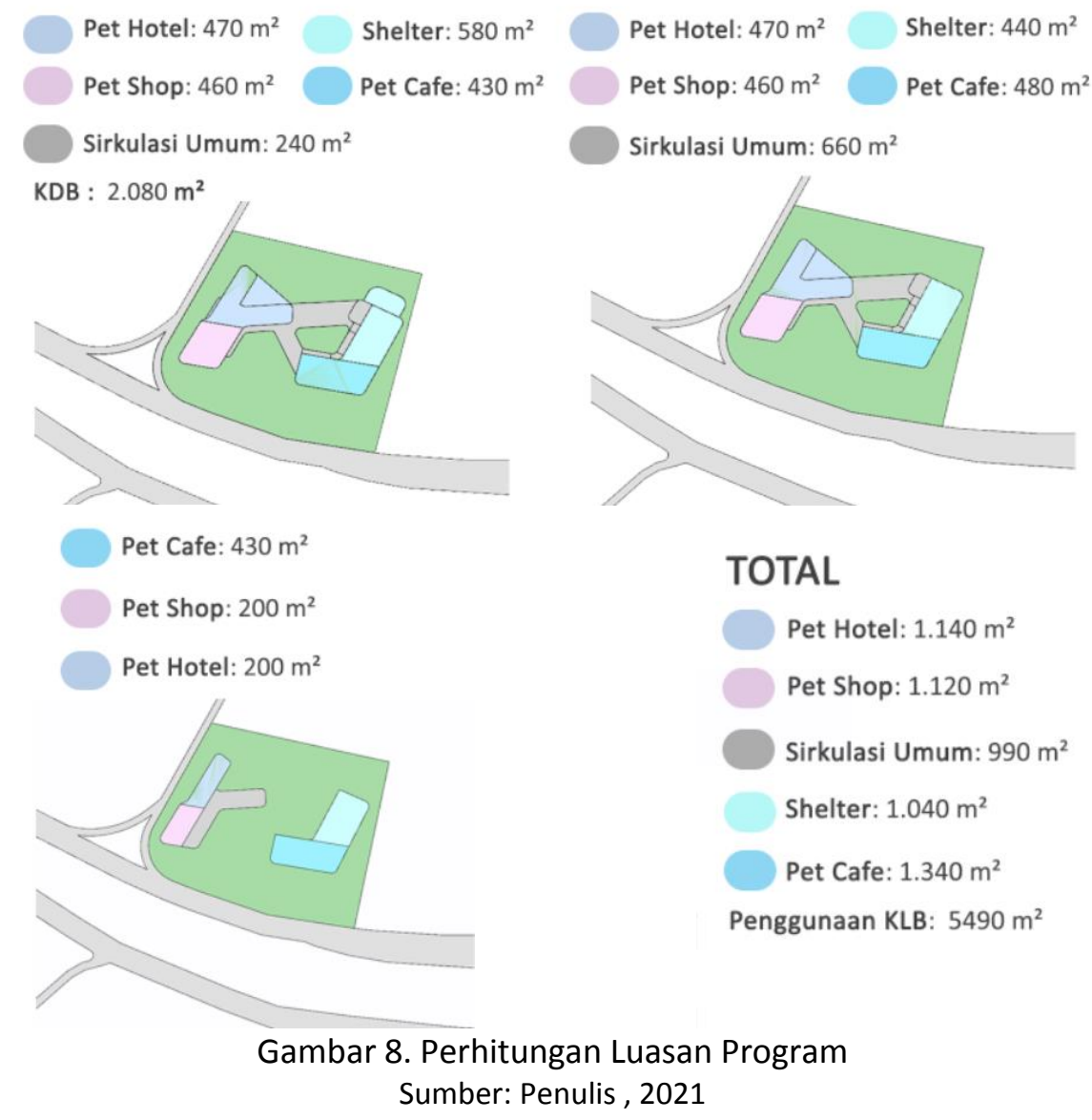




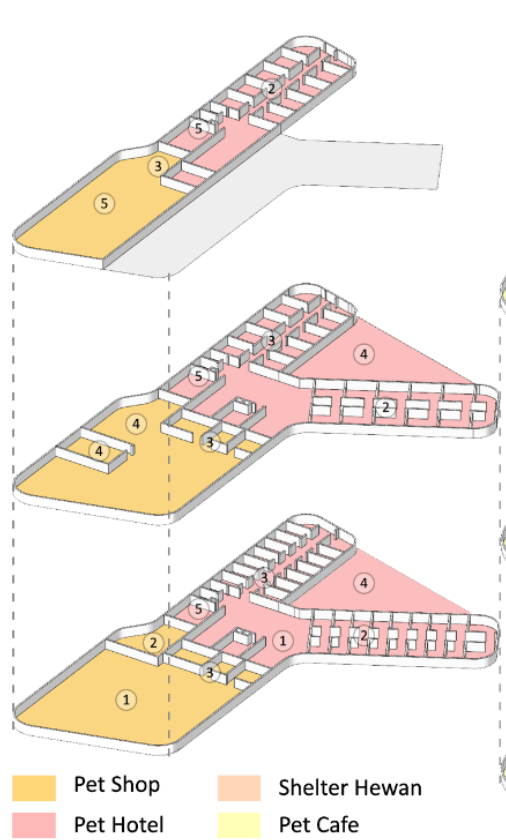

Pet Hote

Pet Cafe

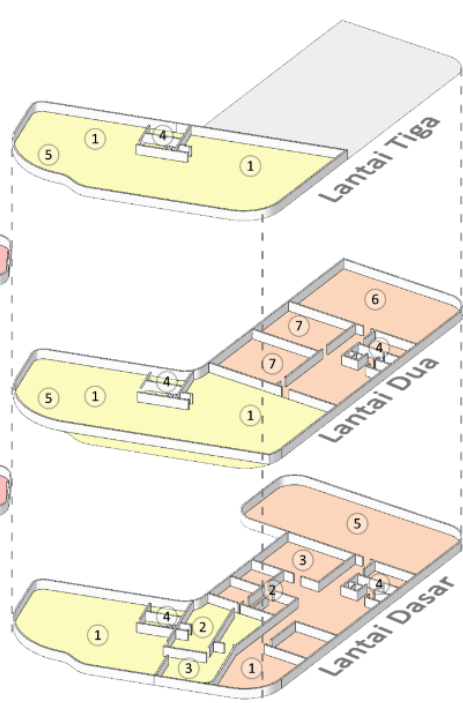

Gambar 9. Program Kegiatan

Sumber: Penulis ,2021

\section{Konsep Perancangan}

Pet Hotel
1. Lobi
2. Koridor Kamar Kucing
3. Koridor Kamar Anjing
4. Area Komunal Tamu
5. Area Service
Pet Shop
1. Area Berbelanja
2. Gudang
3. Area Service
4. Pet Salon dan Pet Studio
5. Tenant disewakan

Shelter Hewan Terlantar 1. Lobi

2. Klinik

3. R. Rehabilitasi

4. Area Service

5. Kandang Bersama Anjing

6. Kandang Bersama Kucing

7. R. Isolasi

Pet Cafe

1. Area Makan

2. Dapur

3. Area Service

4. Toilet

5. Area Bermain

Metode Behavior

Pemilihan konsep kucing dikarenakan bangunan ini akan lebih fokus pada penanganan kucing terlantar, karena anjing-anjing terlantar di jalanan telah banyak ditangani oleh pemerintah daerah. Rancangan gubahan massa mengambil inspirasi dari sifat kelenturan kucing yang seperti "air". Selain secara bentuk, inspirasi kucing ini juga diterapkan dengan rute sirkulasi vertikal menggunakan ramp yang nampak seperti sifat kucing yang jalannya lincah "ke sana ke sini" seperti yang diilustrasikan pada gambar 10.
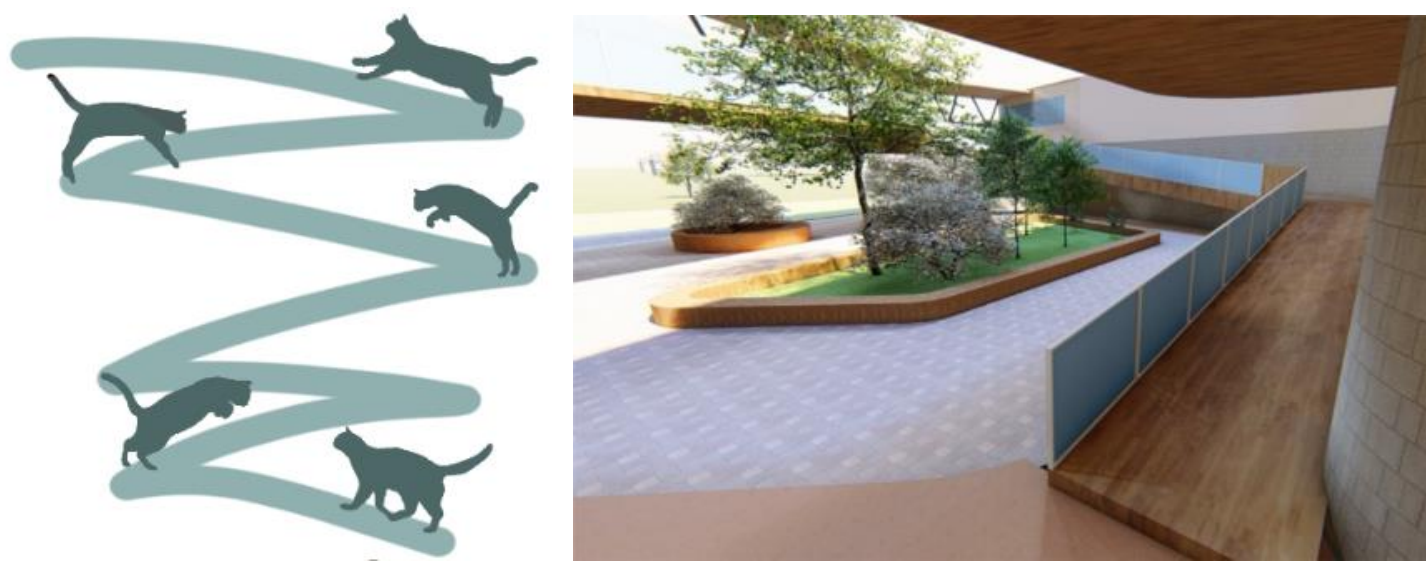

Gambar 10. Ilustrasi Konsep Perancangan dan Pengaplikasiannya

Sumber: Penulis , 2021

Metode Metafora

Bentuk massa juga mengadaptasi bentuk ekor kucing, di mana ekor kucing menggambarkan emosi dan perasaan kucing. Bentuk yang dipilih ialah bentuk ekor kucing yang menggambarkan keinginan seekor kucing untuk berteman seperti ilustrasi pada gambar 11 . 

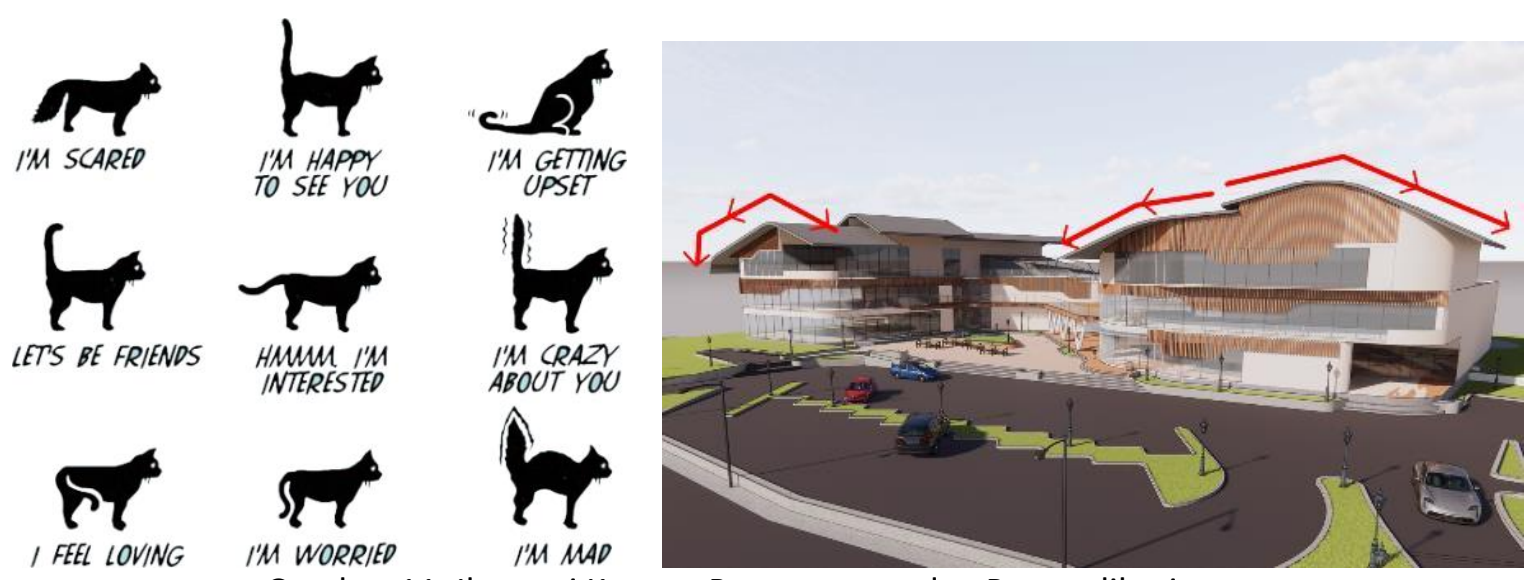

Gambar 11. Ilustrasi Konsep Perancangan dan Pengaplikasiannya

Sumber: Penulis , 2021

\section{Struktural}

Rangka bangunan menggunakan struktur beton bertulang, dengan kolom beton berdimensi $30 \mathrm{~cm}$ dan balok induk 30/60 untuk bentangan 8 meter dan 25/50 untuk bentangan 6 meter seperti yang diilustrasikan pada gambar 12.

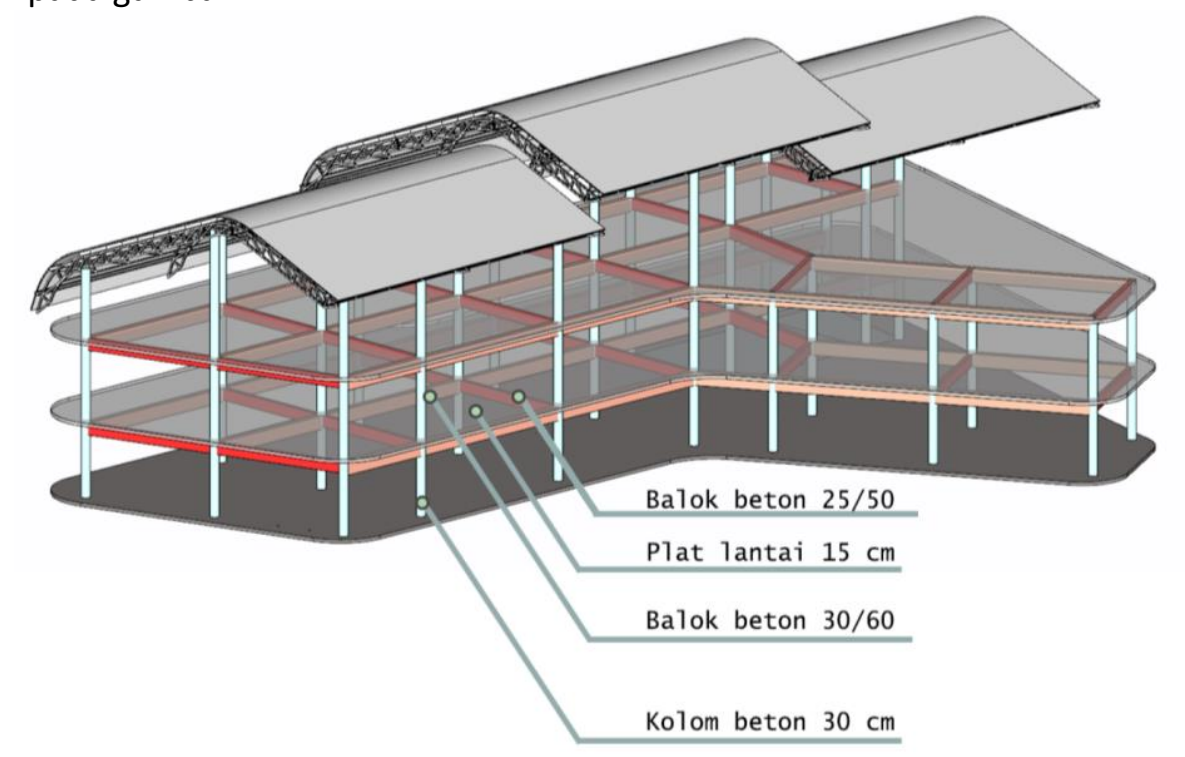

Gambar 12. Struktur Beton Bertulang

Sumber: Penulis, 2021

\section{Desain Rancangan}

Desain rancangan mencakup pada rancanan ruang luar seperti lobi utama dan area terbuka yang dimanfaatkan sebagai area jogging dan pelatihan hewan seperti yang diilustrasikan pada gambar 13.
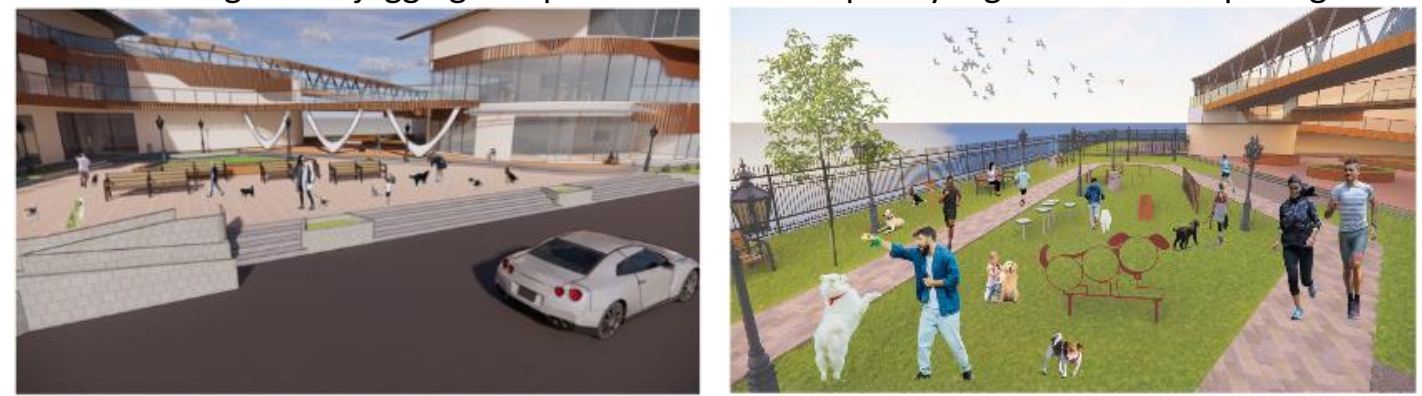

Gambar 13. Suasana Ruang Luar Rancangan

Sumber: Penulis, 2021 
Desain interior dari rancangan juga memperhatikan unsur estetika dan fungsional seperti yang tergambar di gambar 14 dan 15, di mana setiap fungsi memiliki interior yang berbeda tema namun tetap mengedepankan kenyamanan dari pengguna yakni manusia dan hewan.

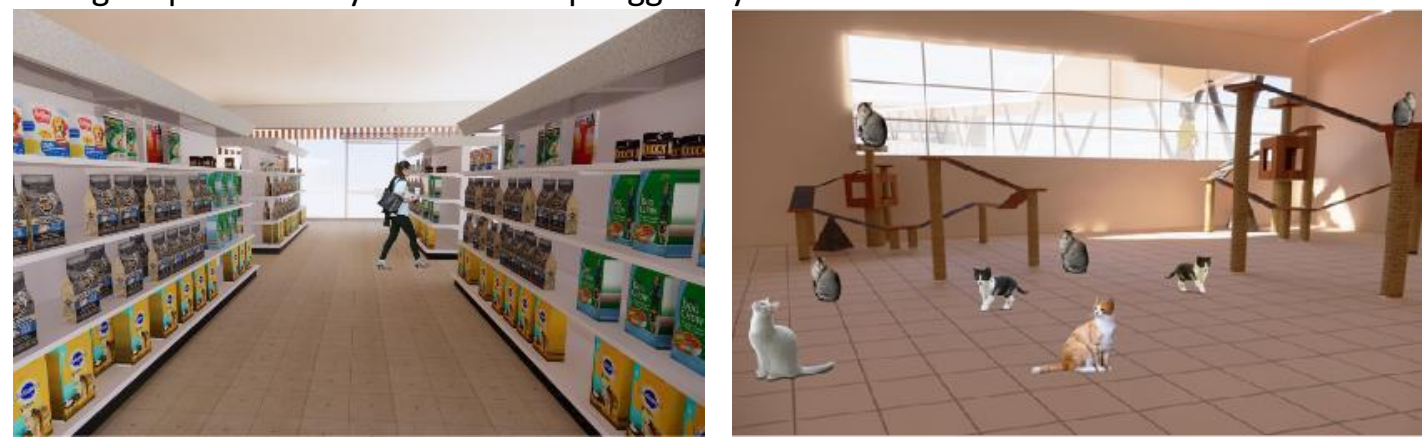

Gambar 14. Suasana Interior Pet Shop dan Shelter Sumber: Penulis, 2021
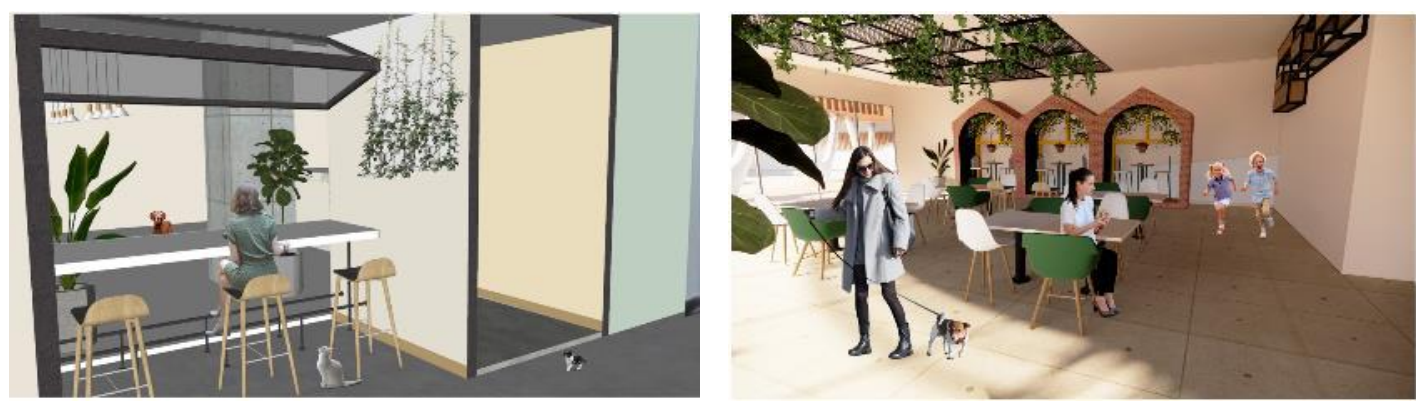

Gambar 15. Suasana Interior Pet Café Sumber: Penulis , 2021

\section{KESIMPULAN DAN SARAN}

\section{Kesimpulan}

Proyek ini hadir sebagai sebuah program desain yang dapat menjadi solusi untuk penanganan hewan terlantar di perkotaan serta mendekatkan kembali hubungan antara hewan peliharaan dengan masyarakat kota. Dengan turut menyelesaikan permasalahan pada hewan terlantar di perkotaan, diharapkan kehidupan perkotaan dapat berjalan dengan semakin dinamis, antara manusia dan unsur alam lainnya seperti hewan dapat berjalan beriringan membentuk suatu ekologi yang baik.

\section{Saran}

Hewan terlantar di jalanan perkotaan perlu mendapat perhatian lebih dari masyarakat maupun pemerintah. Proyek ini baru mencakup pada hewan-hewan terlantar di perkotaan seperti kucing dan anjing, padahal sesungguhnya ada banyak makhluk hidup lain yang juga terganggu ekosistemnya akibat pembangunan kota dan kehidupan kota beserta masyarakatnya. Untuk itu kedepannya sebaik dipikirkan lagi solusi-solusi baru untuk merangkul berbagai ekosistem dalam kota supaya tercipta kehidupan yang dinamis dan seimbang antara berbagai makhluk hidup.s

\section{REFERENSI}

Azhar, M. M., Butarbular, R. M., Ekowati, R. V., Ermawanto, Emawati, Hukmi, A., Kurniawan, W. E., Nurtanto, S., Pujiatmoko, Rasa, F. S. T., Suseno, P. P., Wicaksono, A., \& Yupiana, Y. (2019). National Master Plan for Eradicating Rabies in Indonesia. Direktorat Jendral Peternakan Dan Kesehatan Hewan Kementerian Pertanian, 1-100. http://keswan.ditjenpkh.pertanian.go.id/?p=2681

Burgos-Cáceres, S. (2011). Canine rabies: A looming threat to public. Animals, 1(4), 326-342. 
Coppinger, R. (2001). Dogs: A Startling New Understanding of Canine Origin, Behavior \& Evolution. New York: Scribner.

Garrity, T.F., Stallones, L., Mark, M.B \& Johnson, T.P. (1989). Pet Ownership and Attachment as Supportive Faktor in the Health of the Eldery. Antrozoos, 3(1), 35-44

Grandgeorge, M., \& Hausberger, M. (2011). Human-animal relationships : from daily life to animalassisted therapies. May 2014.

Guilloux, A. G. A., Panachão, L. I., Alves, A. J. S., Zetun, C. B., Cassenote, A. J. F., \& Dias, R. A. (2018). Stray dogs in urban fragments: Relation between population's perception of their presence and socio-demographic factors. Pesquisa Veterinaria Brasileira, 38(1), 89-93.

Kennedy, B. P. A., Cumming, B., \& Brown, W. Y. (2020). Global strategies for population management of domestic cats (Felis catus): A systematic review to inform best practice management for remote indigenous communities in Australia. Animals, 10(4).

Knobel DL, Kaare M, Fevre E, Cleaveland S. (2007). Dog Rabies and its Control.In Jackson AC, Wunner WH (Ed).Rabies. 2nd ed. USA: Elsevier Inc. Pp 573-594.

J, McNicholas. (2010). Dogs as catalysts for social interactions: Robustness of the effect. British journal of psychology.

Miternique, H. C., \& Gaunet, F. (2020). Coexistence of diversified dog socialities and territorialities in the city of concepción, chile. Animals, 10(2).

Mitsui, K., Sato, S., \& Kakuma, Y. (2020). Effects of the Community Cats Program on Population Control, Migration, and Welfare Status of Free-Roaming Cats in Tokyo, Japan. Animals, 1-12.

Pratama, R. (2020). Menerka Jumlah Kucing di Jakarta hingga Tahun 2021. Diakses pada 25 Februari 2021. https://kumparan.com/kumparannews/menerka-jumlah-kucing-di-jakarta-hingga-tahun2021-1547206689104270805

Riza, A. (2020). Detik-detik 4 Pelaku Pukuli Anjing dengan Kayu hingga Mati di Bali. Diakses 24 Februari 2021. https://news.detik.com/berita/d-5071608/detik-detik-4-pelaku-pukuli-anjing-dengankayu-hingga-mati-di-bali

Serpell, J. A. (2013). Domestication and history of the cat. The Domestic Cat: The Biology of Its. Cambridge: Cambridge University Press.

Setiawaty, V., Septiawati, C., \& Burni, E. (2019). Karakteristik Kasus Fatal Akibat Gigitan Hewan Penular Rabies di Indonesia 2016 - 2017. Media Penelitian Dan Pengembangan Kesehatan, 29(3), 235242. April, 83-100. 
